fournal of Medical Genetics (1973). 10, 328.

\title{
Parental Dermatoglyphics in Down's Syndrome. A Ten-year Study
}

\author{
J. H. PRIEST, C. VERHULST, and S. SIRKIN \\ Department of Pediatrics, Section of Medical Genetics, Emory University, Atlanta, Georgia 30322, USA
}

Summary. Fathers and mothers of Down's syndrome cases show dermal microsymptoms when a large series of parents are compared to the general population. A Walker dermal index score in the overlap range $(-2.99$ to +3.00$)$ is more likely to occur in fathers of age-dependent Down's syndrome cases (mean paternal age 40, range 25 to 54 years) and in Down's syndrome mothers than in the general population. The relative risk for these fathers to have a dermal index in the overlap range is two times the risk for male controls; the corresponding risk for mothers of Down's syndrome cases is 1.6 times that for female controls. Thus a score in the overlap range may be used to indicate a group of parents at higher risk for recurrence and occurrence of trisomy 21 offspring. This higher risk parent group can be offered cytogenetic studies, including amniocentesis and chromosome analysis on peripheral blood and skin, as dictated by clinical circumstances.

From a comparison of dermal indexes in these studies, the contribution of maternal mosaicism to all cases of Down's syndrome is estimated to be about $11 \%$ and the contribution of paternal mosaicism about $8 \%$. The contribution from mosaicism in the father but not in the mother appears to increase with parental age. To confirm these estimates, more parents with trisomy 21 mosaicism and trisomy 21 offspring must be diagnosed and studied quantitatively for dermal microsymptoms.

In a previous study (Priest, 1969) mothers of ageindependent Down's syndrome cases were found to resemble their affected offspring when dermatoglyphics were studied by the total dermal index of Norma Ford Walker (1958). Furthermore, when parents with and without Down's offspring were compared, the fathers of Down's syndrome cases had significantly higher dermal indexes than the fathers of non-Down's cases. Thus both fathers and mothers tended, on the average, to resemble their Down's syndrome offspring dermatoglyphically. The present paper summarizes a much larger series of individuals and considers the question whether dermal indexes can be used to delineate parents with high risk for 21 trisomy offspring.

\section{Subjects and Methods}

The parent group consisted of 140 fathers and 156 mothers of index cases with clinical Down's syndrome, approximately $75 \%$ confirmed to have $G$ trisomy by cytogenetic analysis of peripheral blood. Families with known translocation Down's syndrome were excluded.
The control group of 204 were clinically normal, unrelated individuals from families without known chromosomal defect.

Both ink* and inkless $\nmid$ printing materials were used to print fingers, palms, and feet. The Walker index (1958) was used to analyse the prints. Included in this analysis are 16 discriminates: 10 digital patterns, the position of two palmar axial triradii, two third interdigital patterns, and two plantar hallucal areas. Walker based the total dermal index on the frequencies of Down's syndrome to control patterns expressed as logarithms. Down's patterns score greater than +3.00 and include $76 \%$ of index cases in our study. Control (non-Down's) patterns score -3.00 or less and include $72 \%$ of controls in our study. The range of overlap is therefore defined as a score between +3.00 and -2.99 , for the material reported here and also in the original report of Norma Ford Walker.

\section{Results}

Table I summarizes mean dermal indexes by

Received 24 April 1973.

* Hollister Inc, Chicago.

† Faurot, Inc, New York. 
TABLE I

MEAN DERMAL INDEXES BY MATERNAL AGE (MA) BELOW 35 YEARS AND 35 YEARS OR OVER Is there a significant difference in mean dermal index between the two listed sets (A vs $\mathrm{B}$ )?

\begin{tabular}{|c|c|c|c|c|c|c|c|c|}
\hline \multicolumn{3}{|c|}{ Set A } & \multicolumn{3}{|c|}{ Set B } & \multicolumn{3}{|c|}{ Student's t Test (A vs B) } \\
\hline & Number & $\begin{array}{l}\text { Mean Dermal } \\
\text { Index (SD) }\end{array}$ & & Number & $\begin{array}{l}\text { Mean Dermal } \\
\text { Index (SD) }\end{array}$ & t-Value & $\begin{array}{l}\text { One-tail } \\
\text { Probability }\end{array}$ & $\begin{array}{l}\text { Significant } \\
\text { at } 0.05\end{array}$ \\
\hline $\begin{array}{l}\text { Male controls } \\
\text { Male controls } \\
\text { Male controls } \\
\text { Male controls } \\
\text { Female controls } \\
\text { Female controls } \\
\text { Female controls }\end{array}$ & $\begin{array}{r}111 \\
111 \\
111 \\
111 \\
93 \\
93 \\
93\end{array}$ & $\begin{array}{l}-4.09 \pm 1.54 \\
-4.09 \pm 1.54 \\
-4.09 \pm 1.54 \\
-4.09 \pm 1.54 \\
-3.54 \pm 1.71 \\
-3.54 \pm 1.71 \\
-3.54 \pm 1.71\end{array}$ & $\begin{array}{l}\text { Female controls } \\
\text { Fathers (all } M A) \\
\text { Fathers }(M A \geqslant 35) \\
\text { Fathers }(M A<35) \\
\text { Mothers (all } M A) \\
\text { Mothers }(M A \geqslant 35) \\
\text { Mothers }(M A<35)\end{array}$ & $\begin{array}{r}93 \\
140 \\
39 \\
101 \\
156 \\
39 \\
117\end{array}$ & $\begin{array}{l}-3.54 \pm 1.71 \\
-3.78 \pm 1.65 \\
-3.42 \pm 1.83 \\
-3.92 \pm 1.56 \\
-3.14 \pm 1.89 \\
-3.21 \pm 1.76 \\
-3.12 \pm 1.93\end{array}$ & $\begin{array}{l}2.41 \\
1.50 \\
2.19 \\
0.78 \\
1.67 \\
1.00 \\
1.65\end{array}$ & $\begin{array}{l}0.006 \\
0.07 \\
0.02 \\
0.22 \\
0.05 \\
0.16 \\
0.05\end{array}$ & $\begin{array}{l}\text { Yes } \\
\text { No } \\
\text { Yes } \\
\text { No } \\
\text { Yes } \\
\text { No } \\
\text { Yes }\end{array}$ \\
\hline
\end{tabular}

maternal age (MA) expressed as less than 35 years and 35 years or over. Student's $t$ test was used for statistical analysis. Parental ages in these two MA groups are summarized in Table II. Fathers in the older MA group have significantly higher dermal indexes than male controls. Mothers in the younger MA group are significantly higher than female controls. A finding not reported in the smaller study

TABLE II

PARENTAL AGES AT CONCEPTION OF A DOWN'S SYNDROME OFFSPRING, BY MATERNAL AGE (MA)

\begin{tabular}{l|c|c|c|c}
\hline & \multicolumn{2}{|c|}{ MA $<35$ Years } & \multicolumn{2}{c}{ MA $\geqslant 35$ Years } \\
\cline { 2 - 4 } \cline { 5 - 5 } & Fathers & Mothers & Fathers & Mothers \\
\cline { 1 - 2 } $\begin{array}{l}\text { Mean (yr) } \\
\text { Range }\end{array}$ & 27 & 25 & 40 & 39 \\
\hline
\end{tabular}

previously published (Priest, 1969) is a significant difference between male and female controls; thus statistical comparisons of mean dermal indexes between control and parent groups are matched for sex in this report. A one-tail probability figure is acceptable in this analysis because of our initial hypothesis that parents tend, on the average, to resemble their Down's syndrome offspring dermatoglyphically. Therefore, the patients' dermal indexes cannot be either more positive or more negative than controls but can vary only in one direction.
Table III summarizes mean dermal indexes by MA expressed by 10 -year intervals: 15 to 24 years, 25 to 34 years, and 35 to 44 years. Indexes of fathers in the oldest MA group are significantly higher by Student's $t$ test than male controls. Indexes of mothers in the MA group 25 to 34 years are significantly higher than female controls. Within the Down's syndrome parent group the dermal indexes for the various MA groups are not significantly different from each other by Student's t test (probabilities are not shown in Table III).

Table IV summarizes the number of individuals in two MA groups (less than 35 years and 35 years or more) with dermal indexes in the overlap range $(-2.99$ to +3.00$)$. Controls and Down's syndrome parents are compared and significance of differences analysed by the Fisher exact probability test (Siegal, 1956). Chi-square analysis gave similar results; however, Fisher's test is the method of choice here because it provides exact probabilities while chisquare analysis provides only an estimate of probabilities. The number of individuals with scores in the overlap range are significantly higher for the following (1) fathers in the old MA group compared to male controls; (2) all mothers compared to all controls and compared to female controls; (3) young mothers (MA less than 35) compared to all controls and female controls. There was no significant difference between male and female controls.

In Table $\mathrm{V}$ the five sets from Table IV showing

TABLE III

MEAN DERMAL INDEXES BY MATERNAL AGE (MA) 15 TO 24, 25 TO 34, AND 35 TO 44 YEARS Is there a significant difference in mean dermal index between the two listed sets (A vs $\mathrm{B})$ ?

\begin{tabular}{|c|c|c|c|c|c|c|c|c|}
\hline \multicolumn{3}{|c|}{ Set A } & \multicolumn{3}{|c|}{ Set B } & \multicolumn{3}{|c|}{ Student's t Test (A vs B) } \\
\hline & Number & $\begin{array}{l}\text { Mean Dermal } \\
\text { Index (SD) }\end{array}$ & & Number & $\begin{array}{l}\text { Mean Dermal } \\
\text { Index (SD) }\end{array}$ & $\mathrm{t}$-Value & $\begin{array}{c}\text { One-tail } \\
\text { Probability }\end{array}$ & $\begin{array}{l}\text { Significant } \\
\text { at } 0.05\end{array}$ \\
\hline $\begin{array}{l}\text { Male controls } \\
\text { Male controls } \\
\text { Male controls } \\
\text { Female controls } \\
\text { Female controls } \\
\text { Female controls }\end{array}$ & $\begin{array}{r}111 \\
111 \\
111 \\
93 \\
93 \\
93\end{array}$ & $\begin{array}{l}-4.09 \pm 1.54 \\
-4.09 \pm 1.54 \\
-4.09 \pm 1.54 \\
-3.54 \pm 1.71 \\
-3.54 \pm 1.71 \\
-3.54 \pm 1.71\end{array}$ & $\begin{array}{l}\text { Fathers (MA 15-24) } \\
\text { Fathers (MA 25-34) } \\
\text { Fathers (MA 35-44) } \\
\text { Mothers (MA 15-24) } \\
\text { Mothers (MA 25-34) } \\
\text { Mothers (MA 35-44) }\end{array}$ & $\begin{array}{l}41 \\
50 \\
39 \\
50 \\
57 \\
39\end{array}$ & $\begin{array}{l}-3 \cdot 76 \pm 1 \cdot 28 \\
-3 \cdot 99 \pm 1 \cdot 74 \\
-3 \cdot 42 \pm 1 \cdot 83 \\
-3 \cdot 29 \pm 1 \cdot 72 \\
-2 \cdot 98 \pm 2 \cdot 14 \\
-3 \cdot 21 \pm 1 \cdot 76\end{array}$ & $\begin{array}{l}1 \cdot 21 \\
0 \cdot 33 \\
2 \cdot 19 \\
0 \cdot 82 \\
1 \cdot 76 \\
1 \cdot 00\end{array}$ & $\begin{array}{l}0 \cdot 12 \\
0 \cdot 37 \\
0 \cdot 015 \\
0 \cdot 21 \\
0 \cdot 04 \\
0 \cdot 16\end{array}$ & $\begin{array}{l}\text { No } \\
\text { No } \\
\text { Yes } \\
\text { No } \\
\text { Yes } \\
\text { No }\end{array}$ \\
\hline
\end{tabular}


TABLE IV

INDIVIDUALS WITH DERMAL INDEXES IN THE OVERLAP RANGE (-2.99 TO + 3.00) BY MATERNAL AGE (MA) LESS THAN 35 YEARS AND 35 YEARS OR OVER

Is there a significant difference between the number of individuals in the two listed sets (A $v s$ B)?

\begin{tabular}{|c|c|c|c|c|c|c|c|c|c|}
\hline \multicolumn{4}{|c|}{ Set A } & \multicolumn{4}{|c|}{ Set B } & \multicolumn{2}{|c|}{$\begin{array}{c}\text { Fisher's Exact Test } \\
(\mathrm{A} \text { vs B) }\end{array}$} \\
\hline Controls & $\begin{array}{c}\text { Total } \\
\text { Number }\end{array}$ & $\begin{array}{c}\text { Number in } \\
\text { Overlap } \\
\text { Range }\end{array}$ & $\begin{array}{c}\text { Percentage } \\
\text { Overlap } \\
\text { Range }\end{array}$ & & $\begin{array}{c}\text { Total } \\
\text { Number }\end{array}$ & $\begin{array}{c}\text { Number in } \\
\text { Overlap } \\
\text { Range }\end{array}$ & $\begin{array}{c}\text { Percentage } \\
\text { in Overlap } \\
\text { Range }\end{array}$ & Probability & SD \\
\hline $\begin{array}{l}\text { Males } \\
\text { All } \\
\text { Males } \\
\text { All } \\
\text { All } \\
\text { Males } \\
\text { Males } \\
\text { All } \\
\text { Females } \\
\text { All } \\
\text { All } \\
\text { Females } \\
\text { Females }\end{array}$ & $\begin{array}{r}111 \\
204 \\
111 \\
204 \\
204 \\
111 \\
111 \\
204 \\
93 \\
204 \\
204 \\
93 \\
93\end{array}$ & $\begin{array}{l}29 \\
57 \\
29 \\
57 \\
57 \\
29 \\
29 \\
57 \\
28 \\
57 \\
57 \\
28 \\
28\end{array}$ & $\begin{array}{l}26 \\
28 \\
26 \\
28 \\
28 \\
26 \\
26 \\
28 \\
30 \\
28 \\
28 \\
30 \\
30\end{array}$ & $\begin{array}{l}\text { Female controls } \\
\text { Fathers (all MA) } \\
\text { Fathers (all } M A) \\
\text { Fathers (MA } \geqslant 35 \text { ) } \\
\text { Fathers (MA }<35) \\
\text { Fathers (MA } \geqslant 35 \text { ) } \\
\text { Fathers (MA }<35 \text { ) } \\
\text { Mothers (all MA) } \\
\text { Mothers (all MA) } \\
\text { Mothers (MA } \geqslant 35 \text { ) } \\
\text { Mothers (MA }<35 \text { ) } \\
\text { Mothers }(M A \geqslant 35) \\
\text { Mothers }(M A<35)\end{array}$ & $\begin{array}{r}93 \\
140 \\
140 \\
39 \\
101 \\
39 \\
101 \\
156 \\
156 \\
39 \\
117 \\
39 \\
117\end{array}$ & $\begin{array}{l}28 \\
43 \\
43 \\
16 \\
27 \\
16 \\
27 \\
64 \\
64 \\
15 \\
49 \\
15 \\
49\end{array}$ & $\begin{array}{l}30 \\
31 \\
31 \\
41 \\
27 \\
41 \\
27 \\
41 \\
41 \\
38 \\
42 \\
38 \\
42\end{array}$ & $\begin{array}{l}0.32 \\
0.33 \\
0.26 \\
0.08 \\
0.64 \\
0.06 \\
0.52 \\
0.006 \\
0.05 \\
0.13 \\
0.008 \\
0.23 \\
0.05\end{array}$ & $\begin{array}{l}\text { No } \\
\text { No } \\
\text { No } \\
\text { No } \\
\text { No } \\
\text { Yes } \\
\text { No } \\
\text { Yes } \\
\text { Yes } \\
\text { No } \\
\text { Yes } \\
\text { No } \\
\text { Yes }\end{array}$ \\
\hline
\end{tabular}

TABLE V

RELATIVE RISKS FOR DOWN'S PARENTS TO HAVE DERMAL INDEXES IN THE RANGE OF OVERLAP (-2.99 TO +3.00) COMPARED TO CONTROLS

\begin{tabular}{|c|c|c|c|c|}
\hline \multicolumn{4}{|c|}{ Number of Individuals } & \multirow{2}{*}{ Relative Risk } \\
\hline & $\begin{array}{l}\text { Dermal Index } \\
-2.99 \text { to }+3.00\end{array}$ & $\begin{array}{l}\text { Dermal Index } \\
-3.00 \text { or less }\end{array}$ & Total & \\
\hline $\begin{array}{l}\text { Fathers }(M A \geqslant 35) \\
\text { Male controls }\end{array}$ & $\begin{array}{l}16 \\
29\end{array}$ & $\begin{array}{l}23 \\
82\end{array}$ & $\begin{array}{r}39 \\
111\end{array}$ & $\frac{16 \times 82}{23 \times 29}=2 \cdot 0$ \\
\hline $\begin{array}{l}\text { Mothers (all MA) } \\
\text { All controls }\end{array}$ & $\begin{array}{l}64 \\
57\end{array}$ & $\begin{array}{r}92 \\
147\end{array}$ & $\begin{array}{l}156 \\
204\end{array}$ & $\frac{64 \times 147}{92 \times 57}=1.8$ \\
\hline $\begin{array}{l}\text { Mothers (all MA) } \\
\text { Female controls }\end{array}$ & $\begin{array}{l}64 \\
28\end{array}$ & $\begin{array}{l}92 \\
65\end{array}$ & $\begin{array}{r}156 \\
93\end{array}$ & $\frac{64 \times 65}{92 \times 28}=1.6$ \\
\hline $\begin{array}{l}\text { Mothers }(\mathrm{MA}<35) \\
\text { All controls }\end{array}$ & $\begin{array}{l}49 \\
57\end{array}$ & $\begin{array}{r}68 \\
147\end{array}$ & $\begin{array}{l}117 \\
204\end{array}$ & $\frac{49 \times 147}{68 \times 57}=1.9$ \\
\hline $\begin{array}{l}\text { Mothers }(\text { MA < 35) } \\
\text { Female controls }\end{array}$ & $\begin{array}{l}49 \\
28\end{array}$ & $\begin{array}{l}68 \\
65\end{array}$ & $\begin{array}{r}117 \\
93\end{array}$ & $\frac{49 \times 65}{68 \times 28}=1.7$ \\
\hline
\end{tabular}

significant differences are analysed for relative risks for Down's syndrome parents to have dermal indexes in the range of overlap compared to controls. Fathers in the MA group 35 years or greater have a $\times 2$ risk for a dermal index in the overlap range compared to male controls. Mothers in the MA group 35 years or less have a $\times 1.9$ risk compared to female controls. All Down's mothers have a $\times 1.6$ risk compared to female controls.

\section{Discussion}

In these studies sex significantly influences mean Walker dermal index, females being higher than males. It also seems clear that both mothers and fathers of Down's syndrome cases can be shown to have dermal microsymptoms, defined as elevation of mean dermal index, when maternal age and sex are taken into account. In these studies the dermal microsymptoms are most prominent in fathers when maternal age at conception of a Down's syndrome offspring is 35 years or greater (see Table I). The average paternal age in this group is 40 years (range 25 to 54 years). Mothers of relatively age-independent Down's cases also show dermal microsymptoms (MA less than 34 years, average MA 25 years, range 15-34 years). This latter effect is most striking in the MA group 25 to 34 years rather than in the youngest MA group of 15 to 24 years (see Table III); however, differences in parental dermal indexes between the various MA groups by 10-year intervals are not significant.

Penrose and Smith (1966) postulated that trisomy in the mother might tend to reduce fertility by shortening the reproductive period. In seven affected children of five mosaic mothers, the average maternal age was reported to be 22.7 years; thus, there was no indication of increased maternal 
age. We also find more dermal microsymptoms in younger mothers rather than in the mothers aged 35 or over at conception of a 21 trisomy offspring. Why dermal microsymptoms in fathers show up in the maternal age dependent group of cases with Down's syndrome is unclear. It is possible that increasing age of the father also increases the chance for his trisomy 21 mosaicism to be expressed in his offspring. Information about mosaic parental ages could be obtained from a study of their ages at conception of a Down's case, when one or the other is proved to be mosaic for trisomy 21 . A literature review does not at present provide enough cases to answer this question. It will, therefore, continue to be important for investigators to report trisomy 21/normal mosaicism ascertained through trisomy 21 in their offspring. Reported information should include birth dates of trisomy 21 index cases, both parents, and all four grandparents. This information would also provide additional opportunity to test Penrose's hypothesis that trisomy $21 /$ normal mosaicism is itself dependent on maternal age (Penrose and Smith, 1966).

There is still no proof that dermal microsymptoms represent mosaicism for trisomy 21 although Sachs (1971) has shown a direct relationship between the percentage of trisomic cells in skin or peripheral blood and dermal score by the Walker index. An answer to this problem may come from further quantitative studies of dermatoglyphics in individuals with proved trisomy 21 mosaicism. These studies are in progress (P. V. Tishler, and J. H. Priest; D. Loesch, personal communications). The final correlation of dermal microsymptoms with tendency to produce trisomic offspring may come only from dermatoglyphic studies of mosaic parents who have already produced Down's syndrome offspring. Therefore, such reports should also include quantitative dermal indexes.

In these studies mean dermal index is $11 \%$ higher (and significantly different) in mothers of Down's syndrome offspring compared to females in the general population. If one assumes a direct relationship between dermal microsymptoms and trisomy 21 /normal mosaicism, this difference in mean dermal index gives us an estimate of the contribution of maternal mosaicism to trisomy 21 Down's syndrome. In these studies mean dermal index is $8 \%$ higher in fathers than in male controls (although not significantly different), providing a questionable estimate for the contribution of paternal mosaicism. It is entirely possible that increased size of the male control group as well as the group of fathers in the MA group 35 years or over would make the difference between fathers and male controls significant. (The probability of 0.07 approaches significance in the present study.) Thus as high as $20 \%$ of 21 trisomy Down's syndrome could be due to parental mosaicism (secondary nondisjunction). The influence of maternal and paternal age on secondary non-disjunction must still be determined.

On the basis of frequency of dermatoglyphic microsymptoms in Down's parents, Penrose and Smith (1966) estimated the incidence of Down's syndrome caused by mosaic trisomy in the mother to be about $10 \%$, a similar figure to the estimate in these studies. For fathers, his estimate was $1 \%$, a lower figure than the estimate in these studies. Hsu et al (1971) have reported three families in which the propositi have clinical Down's syndrome and trisomy 21 karyotypes, whereas the phenotypically normal fathers are mosaic for trisomy 21. Mosaic fathers may therefore be more common than previous studies would suggest. Accurate information will come from multiple tissue chromosome examinations of both parents particularly when they have more than one offspring with 21 trisomy or if parental dermal microsymptoms are present.

The Hopkins dermal index (Borgaonkar et al, 1971) has 30 discriminants instead of 16 as in the Walker index. The overlap range is only about $10 \%$ either way; about $90 \%$ of Down's cases fall in the Down's syndrome range. Recall that the Walker index has an overlap in either direction of about $25 \%$. Thus the Hopkins index may prove of value to screen for parental microsymptoms (mosaicism) unless it discriminates too much for clinical Down's syndrome and not enough for parental microsymptoms. The parents reported here who are in the overlap range by the Walker index are being re-scored by the Hopkins index to attempt an answer to this problem.

In the meantime, these studies show that the chance for a Walker score in the overlap range $(-2.99$ to +3.00$)$ is significantly increased for fathers in the maternal age-dependent group (mean paternal age 40, range 25 to 54) and for mothers of Down's syndrome offspring (see Table IV). The risk for this group of fathers is two times the risk for male controls and the risk for mothers is 1.6 times the risk for female controls (see Table V). It is suggested that a score in the overlap range can be used to indicate increased risk for recurrence of trisomic children and probably can be used to screen parents at risk for occurrence of trisomic offspring. Such parents could be offered amniocentesis or cytogenetic evaluation for trisomy 21 mosaicism in skin or peripheral blood, as dictated by clinical circumstances. 
The parent and control groups in these studies were derived from two geographically different areas in the USA: Denver, Colorado and Atlanta, Georgia.

Chromosome analyses were also performed in the cytogenetics laboratory of Dr A. Robinson, Department of Biophysics and Genetics, University of Colorado Medical Center, Denver, Colorado. Dr Robinson has provided additional encouragement and valuable suggestions during the progress of this study.

We are very grateful for the help of Eleanor Reisig and Shari Burns who arranged the visit of patients and helped to take the prints. Dr Janet Stewart assisted with interpretation of prints.

Statistical analyses were performed with the help of Bob Byers (Biometry Department, Emory University) and Dr Godfrey Oakley (Center for Disease Control, Atlanta, Georgia).

This research was supported in part by Research
Grants from the United States Public Health Service (GM 16439 and GM 19268).

\section{REFERENCES}

Borgaonkar, D. S., Davis, M., Bolling, D. R., and Herr, H. M. (1971). Evaluation of dermal patterns in Down's syndrome by predictive discrimination. The fohns Hopkins Medical fournal, 128, 141-152.

Hsu, L. Y. F., Gertner, M., Leiter, E., and Hirschhorn, K. (1971). Paternal trisomy 21 mosaicism and Down's syndrome. American fournal of Human Genetics, 23, 592-601.

Penrose, L. S. and Smith, G. F. (1966). Down's Anomaly, ch. 11. Little, Brown and Company, Boston.

Priest, J. H. (1969). Parental dermatoglyphics in age-independent mongolism. fournal of Medical Genetics, 6, 304-309.

Sachs, E. S. (1971). Trisomy G/Normal Mosaicism. A Cytological and Clinical Investigation. H. E. Stenfert Kroese, Leiden.

Siegal, S. (1956). Non Parametric Statistics for the Behavioral Sciences, pp. 96-104. McGraw-Hill, Tokyo.

Walker, N. F. (1958). The use of dermal configurations in the diagnosis of mogolism. In Pediatric Clinics of North America. Symposium on Recent Clinical Advances, pp. 531-543. Saunders, Philadelphia. 